\title{
Performance Characteristics of a Manually Operated Tamarind Briquetting Machine
}

\author{
Geetesh Sinha* and S. Patel \\ ${ }^{1}$ Department of Agricultural Processing and Food Engineering, Indira Gandhi Krishi \\ Vishwavidyalaya, Raipur 492 012, Chhattisgarh, India
}

*Corresponding author

\section{A B S T R A C T}

\section{Keywords}

Tamarind

Briquetting machine, Pulp, Moisture

Article Info

Accepted:

18 January 2018

Available Online:

10 February 2018
The present research was intended to evaluate the performance of tamarind briquetting machine. The machine was tested with tamarind pulp by alternating its moisture content. The test results indicated a satisfactory working of the prototype and fulfilling the objectives of the study. The average density of briquettes varied from 0.94 to $1.05 \mathrm{~g} / \mathrm{cm}^{3}$. The average pressure applied by the male and female operators was found to be $26.02 \mathrm{kPa}$ and $23.38 \mathrm{kPa}$, respectively. It was possible to obtain a final density $\left(1.05 \mathrm{~g} / \mathrm{cm}^{3}\right)$ of briquette at a constant pressure of $24.76 \mathrm{kPa}$ at each stroke. During testing it is also noticed that both the male and female operators can perform the job efficiently through this machine under similar working condition. It was also observed that the tamarind pulp, having moisture content 19.8 to $27.5 \%$ (wb) was suitable for briquetting.

\section{Introduction}

Tamarind (Tamarindus indica L.) is one of the common fruit trees found grown all over India mostly under rainfed conditions, particularly in Tamil Nadu, Maharashtra, Karnataka, Andhra Pradesh, Madhya Pradesh, Orissa and Chhattisgarh. India produces about 2.5 lakh tonnes of Tamarind pulp annually (Anon, 2016).

In the Chhattisgarh state the yearly production of tamarind is 50,000 tones out of which about 10,000 tones are used for processing and sold to other states (Anon, 2007). In Chhattisgarh, tamarind is produced in many small areas and sold locally by the rural people at a throw away prices. During selling they come across many problems such as handling of large volume which need significant space, consumer acceptability for its quality, high transportation cost etc. To overcome these problems there is a need of densification of the stock which can be accomplished by converting the pulp into small briquettes. The machine is supposed to reduce the volume of seedless tamarind pulp which reduce space requirement, reduce the tendency of darkening effect, provide suitable handling size, provide ease in packaging, improve the appearance of pulp and finally result in value 
addition of the uncompressed tamarind pulp. Briquetting should be done at home or the site level. A manual briquetting machine would be beneficial as it does not require any fuel like electricity or animal power. The device should also be easy to operate by the unskilled villagers which will not only solve the above problems to certain extent but at the same time it may provide opportunities in gearing their livelihood in a better way. It is reported that a seedless mandi price was increases from Rs. 47.80 to 94.17 from the year of 2010-11 to 2015-16 (Fine Admin, 2017).

\section{Materials and Methods}

The cost low briquetting machine was made of locally available materials. It was designed and fabricated at the department of Agricultural Processing and Food Engineering, FAE, IGKV, Raipur (C.G.). Efforts were made to keep the mechanism and operation of the machine as simple as possible. The materials used for the fabrication of different parts of the machine were M.S. angle iron, M.S. plate, M.S. rod, M.S. sheet, M.S. shaft, spring and miscellaneous small items. The main parts include mainframe, upper die, pulp box, base plate, spring loaded vertical shaft and Pedal.

For the performances evaluation of Tamarind Briquetting Machine, different moisture content tamarind pulps were taken. The machine was operated by 3 male and 3 female operators. 3 replicas were done by each operator at a time. During each stroke the force $(\mathrm{kg})$ applied by operator was measured by load cell which is fixed on pedal. The density of the tamarind briquette and applied pressure was calculated. Moreover the cost economics, Break-even point and Payback period calculation was also calculated (Dewett, and Chand, 2004).

\section{Results and Discussion}

The density of $500 \mathrm{~g}$ uncompressed tamarind was $0.42 \mathrm{~g} / \mathrm{cm}^{3}$ and after completion of third stroke, the density of briquette was found to be 1.05 and $1.00 \mathrm{~g} / \mathrm{cm}^{3}$ by the male and female operators, respectively. From the above, there was no appreciable difference in the density of the briquettes made by male and female operators. This indicates that both the operators can perform the job efficiently through this machine under similar working condition. The ranges of pressure applied were found to be 23.54 to $31 \mathrm{kPa}$ with average pressure 26.02 $\mathrm{kPa}$ by the male operators whereas the female operators were apply pressure 19.57 to 25.91 $\mathrm{kPa}$ with average pressure $23.38 \mathrm{kPa}$.

The density of $1 \mathrm{~kg}$ uncompressed tamarind was $0.42 \mathrm{~g} / \mathrm{cm}^{3}$ and after completion of third stroke, the density of briquette was found to be 1.05 by both male and female operators. Hence it was found that the both operators can perform the job efficiently through this machine at same working condition. The ranges of pressure applied were found to be 22.55 to $31.76 \mathrm{kPa}$ with average pressure $26.12 \mathrm{kPa}$ by the male operators whereas the female operators were applied pressure 19.62 to $26.55 \mathrm{kPa}$ with average pressure $23.34 \mathrm{kPa}$.

Densities of Tamarind Briquette at Different Stroke Using Different Moisture Content tamarind Pulp were also performed. Tamarind pulp moisture content (wb) was 16.30, 19.80, 24.0 and $27.50 \%$ after completion of third stroke, the average density of briquettes was found to be $0.94,1.03,1.05$, and $1.05 \mathrm{~g} / \mathrm{cm}^{3}$ respectively. It was observed that when the moisture content of tamarind pulp decreases, the hardness of the tamarind pulp increases. Hence the briquetting process made difficult. It was also observed that the tamarind pulp, having moisture content (wb) 19.8 to $27.5 \%$ was better for briquetting.

The density of tamarind briquette by applying constant pressure on the area of pulp box 237.5 $\mathrm{cm}^{2}$ was reduces gradually at different stroke with constant pressure. The required number of stroke decreases, when the constant pressure applied by the operator at each stroke increases. It was also observed that it was possible to obtain a final density $\left(1.05 \mathrm{~g} / \mathrm{cm}^{3}\right)$ of briquette at a constant pressure of $24.76 \mathrm{kPa}$. 
Briquetting of tamarind by hammering action was carried out with the help of pulp box and a hammer. Putting the tamarind pulp on pulp box and hammering it continuously until the briquette developed. The capacity of manually tamarind briquetting by hammering action was found to be $18-22$ briquette/h for $500 \mathrm{~g}$ briquette and $14-16$ briquette/h for $1 \mathrm{~kg}$ briquette.

The capacity of tamarind briquetting machine was 40 number of briquettes per hour for $500 \mathrm{~g}$ briquette and 30 number of briquettes per hour for $1 \mathrm{~kg}$ briquette. It was observed that the capacity of tamarind briquetting machine was $82 \%$ and $88 \%$ more than the capacity of briquetting by hammering action for $500 \mathrm{~g}$ and $1 \mathrm{~kg}$ briquettes, respectively.

The cost of briquetting was calculated to be Rs.0.95 per $\mathrm{kg}$ for $1 \mathrm{~kg}$ briquettes and Rs. 1.42 per $\mathrm{kg}$ for $500 \mathrm{~g}$ briquettes. The breakeven point was estimated to be 225 and 392 briquettes per year for $1 \mathrm{~kg}$ and $500 \mathrm{~g}$ briquette, respectively. This may be respectively achieved after 7.53 and $7.30 \mathrm{~h}$ of working. The initial investment was estimated to be Rs. 6000. For $1 \mathrm{~kg}$ briquettes, total cost of production was estimated to be Rs. 183307.50 per year and total return was expected to be Rs. 202500. Hence the payback period was estimated to be 0.31 year. For $500 \mathrm{~g}$ briquettes, total cost of production was estimated to be Rs. 129307.50 per year and total return was expected to be Rs. 144000. Hence the payback period was estimated to be 0.41 year.

Performance of the machine was found to be satisfactory under the wide range of moisture content of tamarind pulp. The density of both type briquettes (500 g and $1 \mathrm{~kg}$ ) was found to be $1.05 \mathrm{~g} / \mathrm{cm}^{3}$. It was possible to obtain a final density $\left(1.05 \mathrm{~g} / \mathrm{cm}^{3}\right)$ of briquette at a constant pressure of $24.76 \mathrm{kPa}$ at each stroke. The capacity of tamarind briquetting machine was 40 briquettes per hour for $500 \mathrm{~g}$ briquette and 30 briquettes per hour for $1 \mathrm{~kg}$ briquette.

\section{References}

Anonymous, (2007). Chhattisgarh Rajya Laghu Vanopaj, Bajar Sarvekshan Prativedan, Report published from CGMFPFED. pp. 55-56.

Anonymous, (2016). For Clean, Smart and Profitable Farming: Tamarind, accessed at

https://www.indiaagronet.com/horticultur e/CONTENTS/tamarind.htm accessed on 04.01 .2018

Dewett, K. K. and Chand, A. (2004). Modern economics theory. S. Chand and Company Ltd. pp. 173-175

FineAdmin 2017 Opportunity In Tamarind Processing In India: finetrain empowering small business, accessed at: http://finetrain.com/business-opportunityin-tamarind-processing-in-india/ accessed on 24.11.2017

\section{How to cite this article:}

Geetesh Sinha and Patel, S. 2018. Performance Characteristics of a Manually Operated Tamarind Briquetting Machine. Int.J.Curr.Microbiol.App.Sci. 7(02): 1708-1710.

doi: https://doi.org/10.20546/ijcmas.2018.702.206 